\title{
An Environmentally-Induced Transition from the Flagellated to the Non-flagellated State in Salmonella typhimurium: the Fate of Parental Flagella at Cell Division
}

\author{
By C. QUADLING* AND B. A. D. STOCKER \\ The Guinness-Lister Unit, Lister Institute of Preventive Medicine, \\ Chelsea Bridge Road, London, S.W. 1
}

(Received 15 August 1961)

\section{SUMMARY}

Bacteria in cultures of Salmonella typhimurium LT2 were peritrichously flagellated when grown in nutrient broth at $37^{\circ}$; but most were non-flagellated when grown for 6 mean-generation times or more at $44^{\circ}$. When a culture growing exponentially at $37^{\circ}$ was transferred to $44^{\circ}$, growth continued at about the same rate; but the synthesis of new flagella was largely curtailed. The fate of the parental flagella was studied by staining and counting flagella on bacteria from samples taken during growth at $44^{\circ}$ of cultures first grown at $37^{\circ}$. After 3 mean-generation-times the average number of flagella/flagellated bacterium had fallen from about 8 to about 2 and the proportion of flagellated bacteria from about $100 \%$ to about $60 \%$. The distribution of numbers of flagella/bacterium was at all times unimodal, with the mode decreasing from about 8 to 0 . In nongrowing cultures at $44^{\circ}$ there was little or no change in the average number of flagella/bacterium, in the proportion of flagellated bacteria, or in the distribution of numbers of flagella/bacterium. It is inferred that parental flagella are neither rapidly shed at $44^{\circ}$ nor retained entirely by one daughter cell at each division but are distributed about equally between the two daughter cells.

\section{INTRODUCTION}

Observations on the morphology of bacteria by light and electron microscopy have led some workers to infer that in rod-shaped bacteria the growth of the bacterial cell wall occurs mainly or entirely at one pole. Bisset (1951), Bisset \& Pease (1957) and Bisset \& Hale (1960) examined, by microscopy, preparations of Salmonella spp. and of other rod-shaped organisms. They concluded that during growth and division the portion of the parental cell wall which bore flagella passes in its entirety to one daughter cell, and that the other daughter had a new cell wall and grew new flagella. For ease in discussion of the modes of partition of parental flagella, this view will be called the 'all or none' hypothesis. On the other hand, the results of micromanipulation experiments (Stocker, 1956a, $b$; Quadling \& Stocker, 1957; Quadling, 1958) on the unilinear transmission of motility and, by inference, of flagella, from parent to daughter cells in Salmonella spp. are most readily interpreted by assuming that 'parental' flagella are shared about equally

* Present address: Applied Biology Division, National Research Council, Ottawa, Ontario, Canada. 
between the daughter cells produced at each division. This idea will be referred to as the 'sharing' hypothesis.

We report here an attempt to obtain evidence of the fate of bacterial flagella at cell division, by treating growing cultures of flagellated Salmonella typhimurium so that growth continues but no new flagella are produced. If, as Bisset suggested, the original cell wall and all the flagella of a peritrichously flagellated bacterium pass to one of its daughters, a bimodal distribution of numbers of flagella/bacterium would be expected to develop after the cessation of synthesis of flagella, with an increasing proportion of the population (all those with 'new' cell walls) having no flagella, and a decreasing proportion (those with the original cell walls and flagella) having several flagella each. Alternatively, if the flagella of a multiflagellate bacterium be shared between its daughters, a unimodal distribution would be expected, with the modal number of flagella/bacterium decreasing as the original flagella are distributed amongst the increasing bacterial population.

It was found that the synthesis of flagella by growing bacteria could be suppressed by transferring a logarithmic-phase broth culture of a wild-type flagellated Salmonella typhimurium strain (LT2) from $37^{\circ}$ to $44^{\circ}$. Growth continued at about the same rate as before, but the average number of flagella/bacterium fell from about $8 \cdot 2$ to less than 1 , and the proportion of non-flagellated bacteria increased from less than $5 \%$ to $70 \%$, or more. The chang as in distributions of number of flagella/bacterium were also investigated. Though the suppression of synthesis of flagella was less complete and abrupt than had been hoped, the results obtained are compatible with the hypothesis that parental flagella are shared at bacterial division; they cannot, we think, be reconciled with the alternative hypothesis. A preliminary report of this work has already been given (Quadling \& Stocker, 1956).

\section{METHODS}

Salmonella typhimurium strain LT2 of Zinder \& Lederberg (1952) was used. The cultural methods were described by Quadling \& Stocker (1957). The growth of cultures was followed by turbidity measurements made with a Hilger 'Spekker' photoelectric absorptiometer or by plate counts of viable bacteria made by the method of Miles \& Misra (1938). Cultures were grown in nutrient broth made from a papain digest of lean beef (Asheshov, 1941). Changes in temperature of incubation were effected by diluting cultures into broth at $44^{\circ}$. Cultures were incubated in stationary capped, conical flasks held in a water bath at the appropriate temperature $\left(37^{\circ}, 44^{\circ}\right)$; they were maintained in exponential growth at populations below $10^{8}$ bacteria/ml. by periodic dilution with prewarmed broth.

Staining and counting of flagella were carried out by a modification of Leifson's (1951) method as described by Quadling (1958). The flagella were counted on each of the first five organisms seen in each of ten or more successive scans of stained smears, starting at arbitrarily chcsen points. In some experiments the slides were coded and the counts repeated by one of us who had no knowledge of the times of sampling. This procedure would be expected to decrease observer bias in the selection of organisms for counting. Possible sources of error in observed distributions of numbers of stained flagella were discussed by Quadling (1958). Broth cultures were examined for motility by low-powes: dark-ground microscopy as described by Stocker 
$(1956 b)$. To determine the percentage of organisms which were motile, suitably diluted samples were examined in a Helber chamber. Separate counts of motile and of non-motile organisms were made and the figures combined to yield a percentage value.

\section{RESULTS}

The effect of various treatments on distribution of numbers of flagella

Typical peritrichous flagellation was shown by cultures of strain LT2 grown exponentially in nutrient broth at $37^{\circ}$; the average number flagella/bacterium was about 8 and the proportion of non-flagellated, non-motile, organisms was less than $5 \%$. Distribution of numbers of flagella/bacterium in such cultures are given in Table 1 (entries 1 and 4 ) and in Table 2 (times $15 \mathrm{~min}$. and $-15 \mathrm{~min}$.). In preliminary experiments it was found that when exponentially growing cultures of strain LT2 were transferred to $44^{\circ}$ growth continued at about the same rate as before but the proportion of non-flagellated bacteria increased as growth continued at $44^{\circ}$. To determine whether this increased proportion of non-flagellated bacteria resulted from the suppression of flagellar synthesis or from the rapid shedding of flagella, distributions of numbers of flagella were determined after treatments involving temperature change, with and without growth. It was found that in the absence of growth there was little change in the number flagella/bacterium during incubation at $44^{\circ}$ (Table 1). This was shown for a $37^{\circ}$-grown stationary-phase culture held for $4 \mathrm{hr}$. at $44^{\circ}$, for a formalin-killed $37^{\circ}$-grown log-phase culture held $4 \mathrm{hr}$. at $44^{\circ}$, and also for a $37^{\circ}$-grown log-phase culture incubated for $4 \mathrm{hr}$. at $44^{\circ}$ with $100 \mu \mathrm{g}$. chloramphenicol $/ \mathrm{ml}$. (which arrests growth and prevents synthesis of new flagella). We conclude that flagella grown at $37^{\circ}$ are not rapidly shed at $44^{\circ}$ and that the change from the flagellated to the non-flagellated condition at $44^{\circ}$ is associated with growth of the bacteria rather than with adverse effects on the flagella themselves. When cultures grown at $44^{\circ}$, in which less than $1 \%$ of the bacteria were flagellated, were placed at $37^{\circ}$ the bacteria rapidly regained flagella. In one such experiment $20 \%$ of the bacteria had demonstrable flagella after $30 \mathrm{~min}$. growth at $37^{\circ}$, and $48 \%$ had flagella after $60 \mathrm{~min}$. Such results are evidence that the loss of flagella at $44^{\circ}$ is phenotypic only, and that new flagella are produced on return to a suitable environment.

\section{Effect of growth at $\mathbf{4 4}^{\circ}$ on distribution of numbers of flagella}

To investigate the effects of continued growth at $44^{\circ}$ on the distribution of numbers of parental flagella, the synthesis of new flagella was curtailed by transferring to $44^{\circ}$ an unaerated broth culture which was in logarithmic growth at $37^{\circ}$. Such cultures were maintained in logarithmic growth for over $4 \mathrm{hr}$. by periodic dilution with fresh broth held at $44^{\circ}$ in a water bath. Samples for flagella staining were taken at intervals and fixed with formaldehyde. The growth of cultures was followed by turbidity measurements or by plate counts of viable bacteria: the mean doubling time at both temperatures was about $40 \mathrm{~min}$., but varied from experiment to experiment. The distributions of number of flagella/bacterium were determined by counts of flagella present on 50-200 bacteria from each sample in random fields of smears stained by Leifson's (1951) method. Results are given in Tables 2-4 and are illustrated in Figs. 1-3. In general, little change occurred in the mean number of 


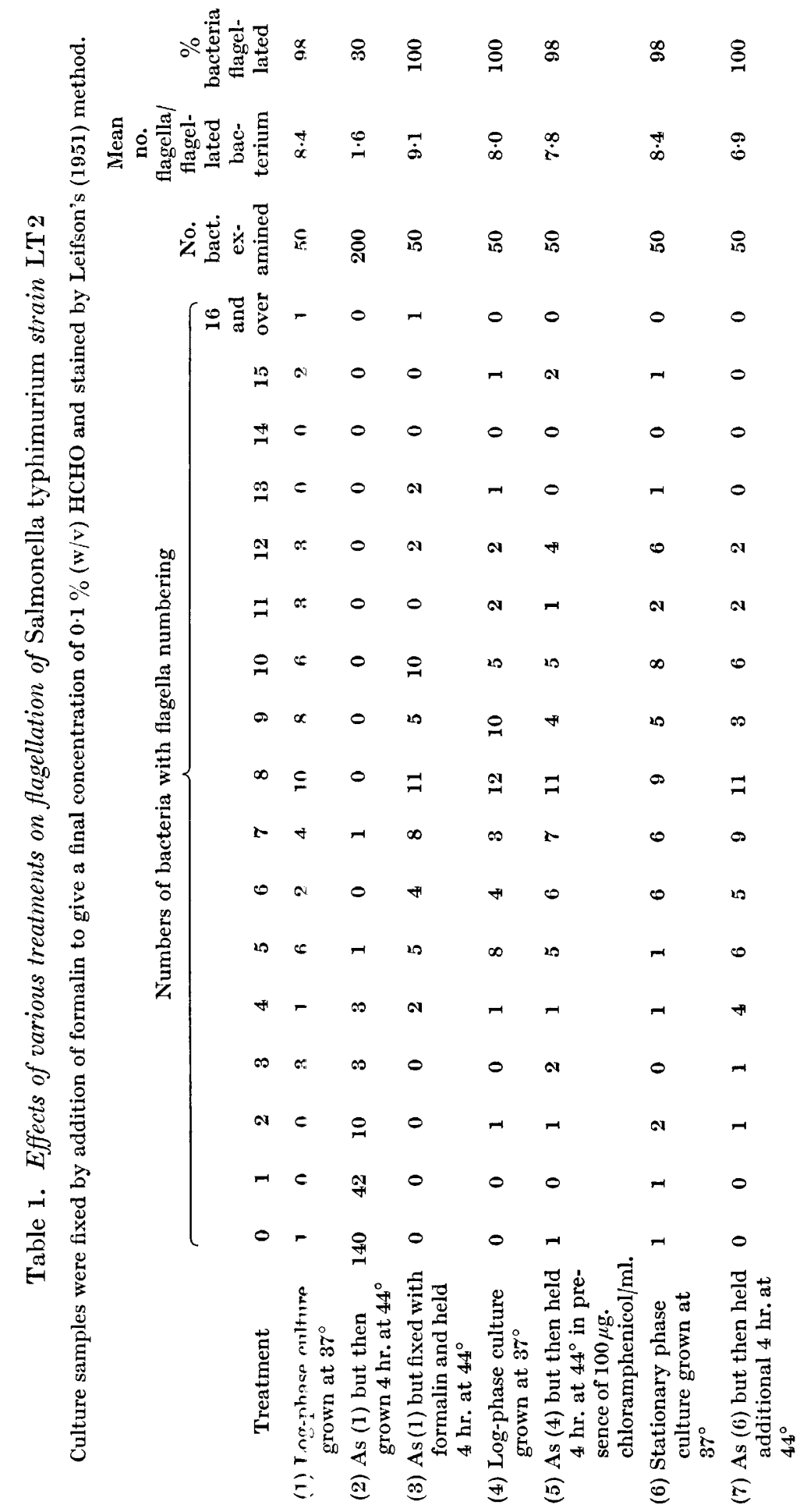




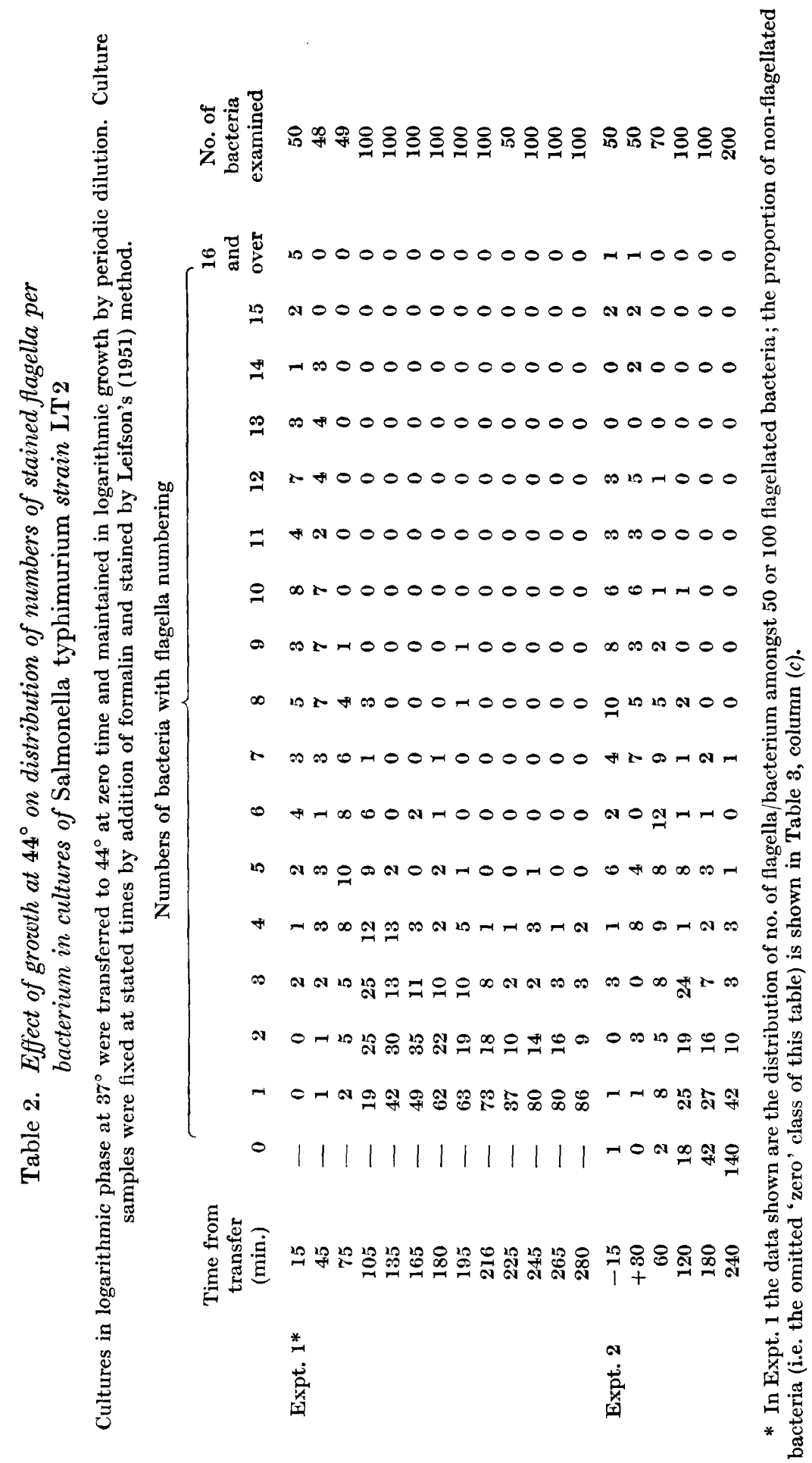


flagella/bacterium during the first doubling time at $44^{\circ}$, but after $60 \mathrm{~min}$. this number decreased; it continued to decrease until most bacteria had no flagella and the few remaining flagellated bacteria had only one or a small number of flagella each.

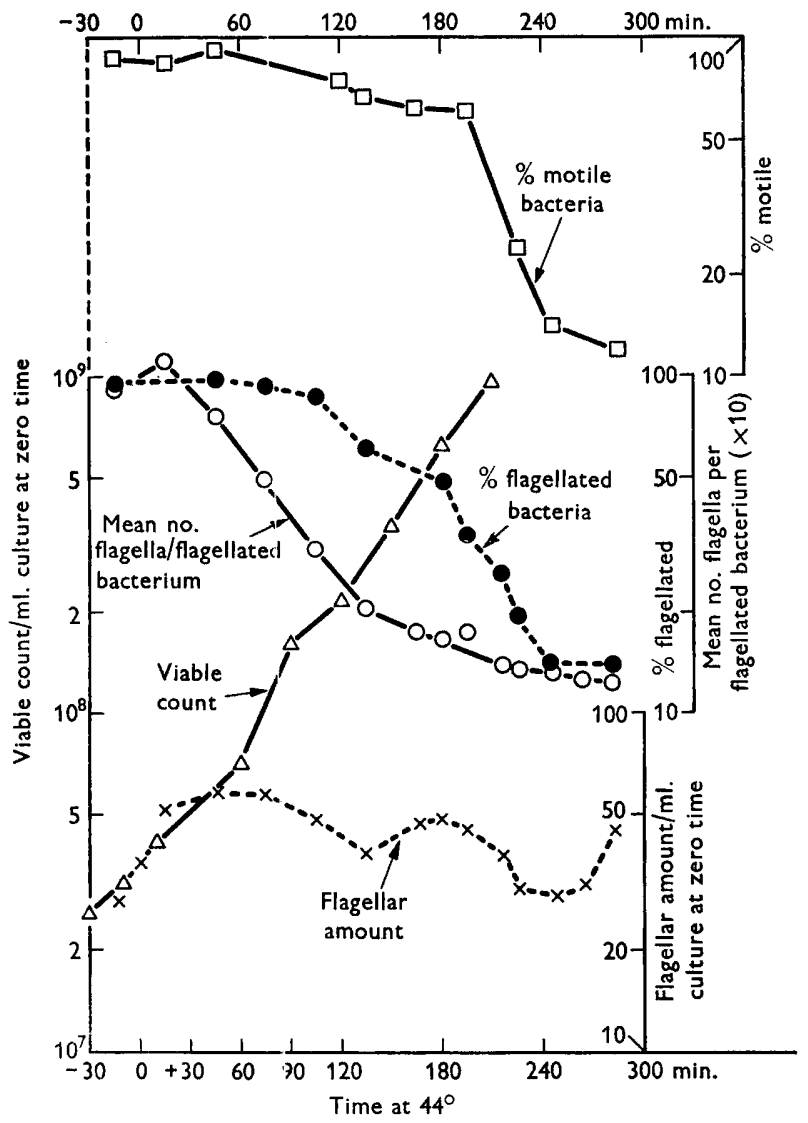

Fig. 1. Effect of growth at $44^{\circ}$ on flagellation and motility of a logarithmic phase culture of Salmonella typhimurium grown at $37^{\circ}$ and transferred to $44^{\circ}$ at time zero. Cultures were maintained in logarithmic growth by periodic dilution with pre-warmed broth at $44^{\circ}$. Samples were fixed at stated times by addition of formalin and stained by Leifson's (1951) method. The data are plotted semi-logarithmically and are from Expt. 1, Tables 2 and 3 . Viable count as plotted is corrected for dilution during growth.

Data from two experiments are shown in graph form as semi-logarithmic plots against time (Figs. 1, 2). There is an excellent correspondence between estimates of the $\%$ motile bacteria and \% flagellated bacteria at the times of sampling (Fig. 1). This is evidence for the reliability of the staining technique and for the lack of any significant loss of flagella during preparation and staining, especially at the later times of sampling. For reference, the reciprocal of 'notional' turbidity is plotted in Fig. 2. Notional turbidity was obtained by adjusting observed turbidities to compensate for the periodic dilution of the starting culture which occurred during the experiment. The slope of this line is a measure of the rate at which the culture was diluting its original cell mass by fresh growth. The mean number of flagella/ 
bacterium decreased from about $45 \mathrm{~min}$. at about the same exponential rate as would be expected if this change were a consequence of dilution by growth. Such a result would be expected if parental flagella were retained only by one daughter bacterium or were shared between both daughters at division. However, the data show that the mean number of flagella per flagellated bacterium also decreased steadily towards unity, instead of remaining constant as predicted by the 'all or none'

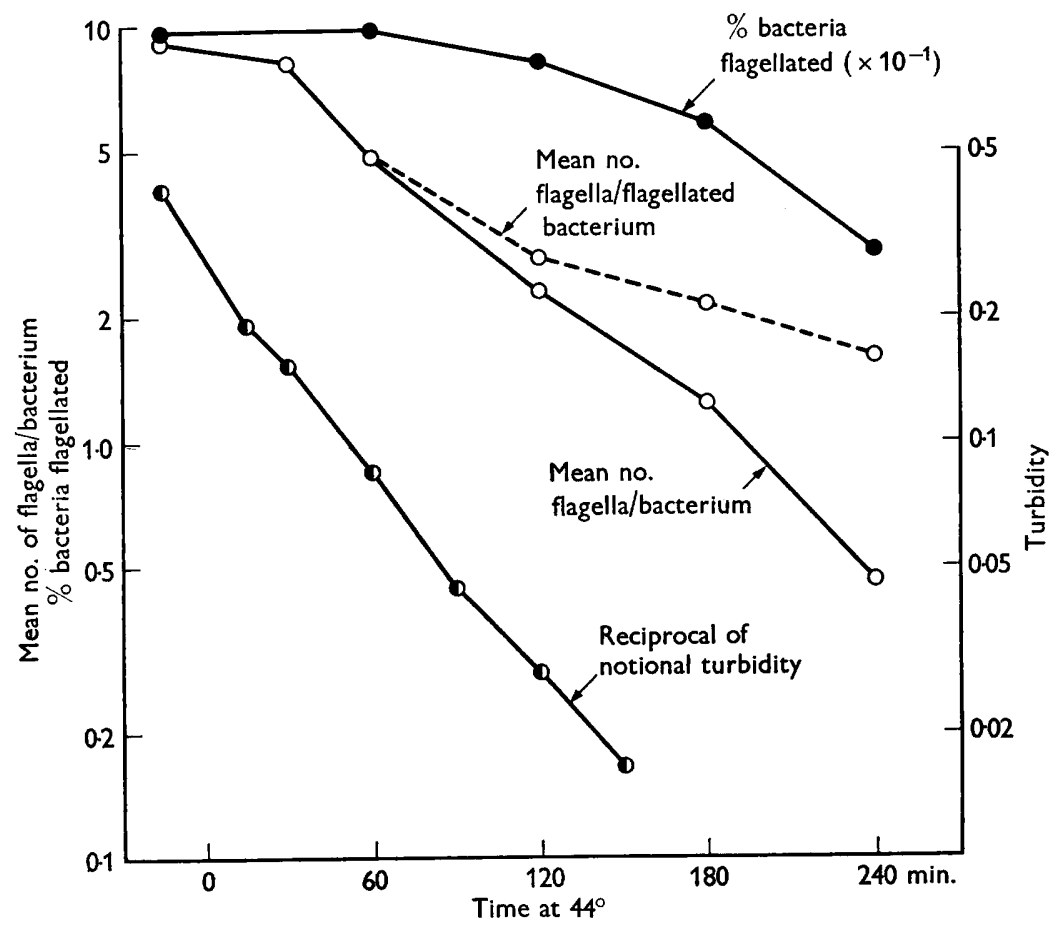

Fig. 2. Effect of growth at $44^{\circ}$ on flagellation of a logarithmic phase culture of $S a l$ monella typhimurium grown at $37^{\circ}$ and transferred to $44^{\circ}$ at zero time. Cultures were maintained in logarithmic growth by periodic dilution with pre-warmed broth at $44^{\circ}$. Samples were fixed at stated times by addition of formalin and stained by Leifson's (1951) method. The data are plotted semi-logarithmically and are from Expt. 2, Tables 2 and 4. Notional turbidity is actual turbidity multiplied by a correction factor for dilution during growth.

hypothesis. Such results, taken in conjunction with: $(a)$ an absolute decrease in numbers of bacteria with large numbers of flagella (Table 5); (b) the demonstrated maintenance of parental flagella at $44^{\circ}$ in the absence of growth (Table 1), are difficult to reconcile with the simple 'all or none' hypothesis that parental flagella are retained entirely by one daughter cell at each division. The initial low rate of decline in the proportion of bacteria with flagella also suggests that such 'all or none' partitioning of peritrichously-inserted flagella did not occur. The distributions of number of flagella/bacterium during incubation at $44^{\circ}$ are illustrated in histogram form in Fig. 3. These distributions were unimodal and did not become bimodal as predicted by the 'all or none' hypothesis discussed in the Introduction and below. 


\section{Residual synthesis of flagella}

The experiments mentioned above were designed to distinguish between the hypotheses: (1) 'all or none' partition; (2) 'sharing' of flagella at cell division. It was thought that a decisive test would be to follow the parameter 'mean number flagella/flagellated bacterium' during the transition from almost $100 \%$ of flagellated organisms to the state in which nearly all were non-flagellated. The 'all or none' hypothesis in its simplest form predicts a decrease in this parameter of, at most, a

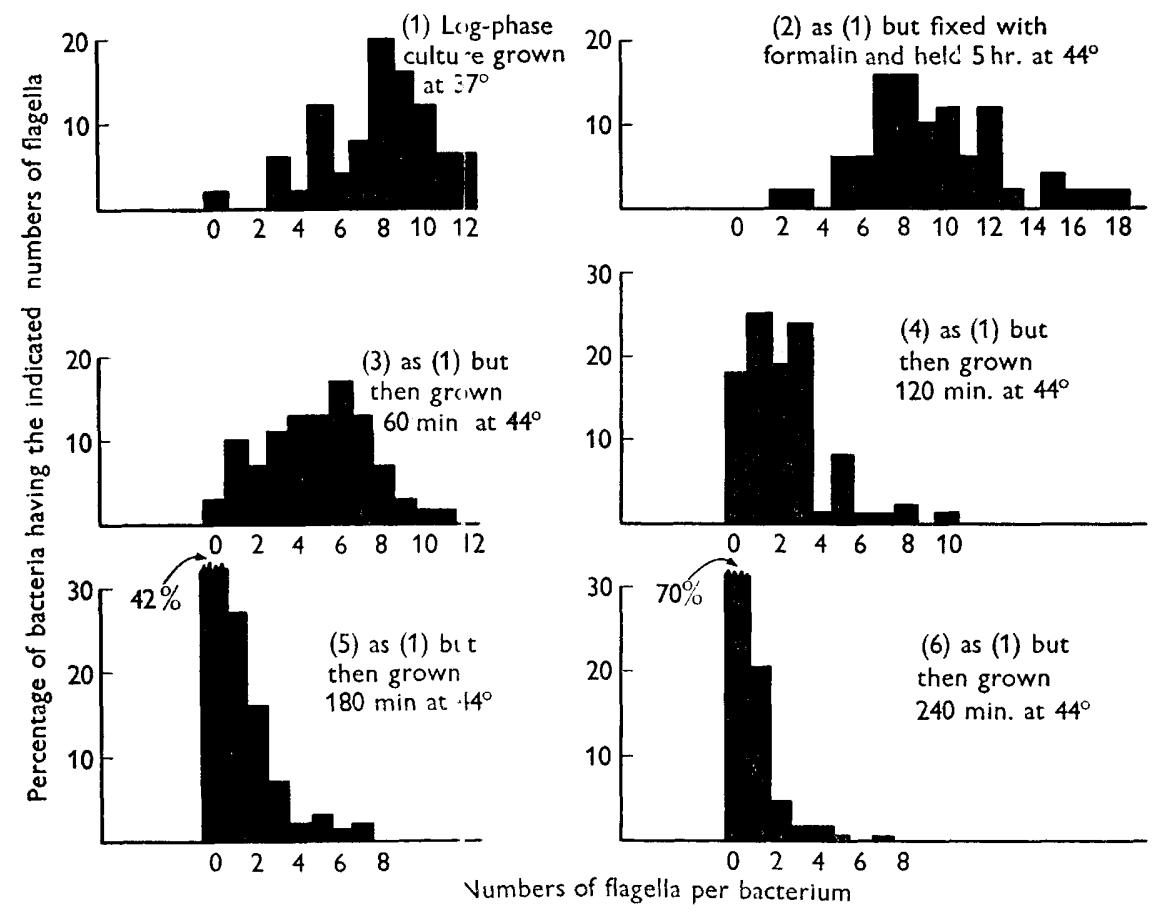

Fig. 3. Effect of incubation at $44^{\circ}$, with and without growth, on the distribution of numbers of flagella per bacterium n Salmonella typhimurium. Data of distributions (3) to (6) inclusive are from Expt. 2, Table 2. Cultures in logarithmic growth at $37^{\circ}$ were transferred to $44^{\circ}$ at zero time and maintained in logarithmic growth by periodic dilution with prewarmed broth at $44^{\circ}$. Samples were fixed at stated times by addition of formalin and stained by Leifson's (1951) me thod.

half (attributable to completion of bacterial divisions in progress at the time of cessation of flagellar synthesis) a d then no further decrease, whilst the 'sharing' hypothesis predicts a steady decli ce towards unity. Although the changes observed in the mean number flagella/fla:yellated bacterium clearly favoured the sharing hypothesis, this result was not in itself sufficient to determine the way in which parental flagella were partitioned at cell division, since it was possible to envisage situations in which a slow decline in rate of synthesis of new flagella might lead to a slow decline in the mean number flagella/flagellated bacterium. Accordingly, the extent of the synthesis of new flasella which occurred after the temnerature chanor 
from the changes in total 'flagellar amount' during experiments. This parameter is estimated by multiplying the mean number flagella/bacterium by the notional turbidity calculated for the culture at the time of sampling or by the calculated notional viable count at the time of sampling (Tables 3,4 ). Notional turbidity or

Table 3. Summary of data* on the effect of growth at $44^{\circ}$ on the motility and flagellation of Salmonella typhimurium strain LT 2

Cultures in logarithmic growth at $37^{\circ}$ were transferred to $44^{\circ}$ at zero time and maintained in logarithmic growth by periodic dilution. Entries in columns $(f),(g)$ and $(h)$ are expressed as per ml. culture at zero time, to allow for dilution.

\begin{tabular}{|c|c|c|c|c|c|c|c|}
\hline $\begin{array}{l}\text { Time } \\
\text { from } \\
\text { transfer } \\
\text { (min.) }\end{array}$ & $\begin{array}{c}\text { Mean no. } \\
\text { of } \\
\text { flagella/ } \\
\text { flagellated } \\
\text { bacterium }\end{array}$ & $\begin{array}{c}\% \text { bacteria } \\
\text { flagellated }\end{array}$ & $\begin{array}{c}\% \\
\text { bacteria } \\
\text { motile }\end{array}$ & $\begin{array}{c}\text { Mean no. } \\
\text { of } \\
\text { flagella/ } \\
\text { bacterium } \\
\left(\frac{=b \times c}{100}\right)\end{array}$ & $\begin{array}{c}\text { Notional } \\
\text { viable } \\
\text { count } \\
\left(\times 10^{7}\right)\end{array}$ & $\begin{array}{c}\text { Smoothed } \\
\text { viable } \\
\text { count } \dagger \\
\left(\times 10^{7}\right)\end{array}$ & $\begin{array}{c}\text { Flagellar } \\
\text { amount } \\
(=e \times g)\end{array}$ \\
\hline$(a)$ & (b) & $(c)$ & $(d)$ & $(e)$ & $(f)$ & (g) & $(h)$ \\
\hline-30 & - & - & - & - & $2 \cdot 62$ & $2 \cdot 6$ & - \\
\hline-15 & $9 \cdot 1$ & $97(116 / 120)$ & 88 & $8 \cdot 8$ & - & $\mathbf{3 \cdot 2}$ & 28 \\
\hline-10 & - & - & - & - & $3 \cdot 4$ & $3 \cdot 4$ & - \\
\hline 0 & - & - & - & - & - & $4 \cdot 0$ & $36+$ \\
\hline 10 & - & - & - & 一 & $4 \cdot 22$ & $4 \cdot 6$ & - \\
\hline 15 & $10 \cdot 1$ & - & 85 & $10 \cdot 1+$ & - & $5 \cdot 0$ & 51 安 \\
\hline 45 & $7 \cdot 63$ & $98(118 / 120)$ & 93 & $7 \cdot 5^{\circ}$ & - & $7 \cdot 9$ & 58 \\
\hline 60 & 一 & - & 一 & - & $7 \cdot 4$ & $9 \cdot 8$ & - \\
\hline 75 & $4 \cdot 9$ & $93(130 / 140)$ & 95 & $4 \cdot 6$ & - & 12 & 55 \\
\hline 90 & - & - & - & - & $16 \cdot 1$ & - & - \\
\hline 105 & $3 \cdot 04$ & $88(70 / 80)$ & - & $2 \cdot 7$ & - & 18 & 49 \\
\hline 120 & 一 & - & 76 & - & $21 \cdot 8$ & 24 & - \\
\hline 135 & $2 \cdot 03$ & $61(82 / 134)$ & 67 & $1 \cdot 2$ & - & 30 & 36 \\
\hline 150 & - & - & - & - & $36 \cdot 3$ & 38 & - \\
\hline 165 & $1 \cdot 76$ & 一 & 62 & $0.97 \ddagger$ & - & 48 & $47 \div$ \\
\hline 180 & $1 \cdot 67$ & $49(90 / 195)$ & - & $0 \cdot 82$ & $63 \cdot 4$ & 60 & 49 \\
\hline 195 & $1 \cdot 73$ & $34(21 / 62)$ & 51 & 0.59 & - & 76 & 45 \\
\hline 210 & - & - & - & - & $96 \cdot 6$ & 94 & - \\
\hline 216 & $1 \cdot 37$ & $25(32 / 126)$ & - & $0 \cdot 34$ & - & 104 & 35 \\
\hline 225 & $1 \cdot 34$ & $19(19 / 100)$ & 24 & $0 \cdot 25$ & - & 118 & 30 \\
\hline 245 & $1 \cdot 31$ & $14(21 / 150)$ & 14 & $0 \cdot 18$ & - & 158 & 28 \\
\hline 265 & $1 \cdot 25$ & $10(16 / 158)$ & 12 & $0 \cdot 13$ & - & 213 & 28 \\
\hline 280 & $1 \cdot 21$ & $14(20 / 142)$ & - & $0 \cdot 17$ & - & 265 & 45 \\
\hline
\end{tabular}

* Expt. 1, Table 2.

$\dagger$ Entries for times $-30 \mathrm{~min}$. to $216 \mathrm{~min}$. inclusive are interpolated; the remainder are extrapolated.

\$ In columns $e$ and $h$ indicates amount calculated from an interpolated value in columns $(b)$ and/or $(c)$.

( ) In column $(c)$ indicates actual figures used in calculation of percentage.

- No observation.

viable count was estimated by taking account of the dilutions which had been made during the experiment and calculating back to obtain the hypothetical value which would have been found had the original culture, undiluted, remained in exponential growth at $44^{\circ}$. Flagellar amount is thus hypothetical and proportional to the total number of flagella/bacterium which would have been present if the whole culture had been maintained in exponential growth. The data in Table 4 (from Exp. 2, Table 2) indicate that total flagellar amount increased slowly throughout $240 \mathrm{~min}$. 
of growth at $44^{\circ}$, with the greatest increase occurring within the first $30 \mathrm{~min}$. (about 1 mean generation time) after the temperature change. In contrast, the data in Table 3 (from Exp. 1, Table 2) show an increase in the first 30-60 min. at $44^{\circ}$, followed by a slow decrease in flagellar amount during the next $180 \mathrm{~min}$. of incuba-

Table 4. Summary of data* on the effects of growth at $44^{\circ}$ on

flagellation of Salmonella typhimurium strain LT2

Culture in logarithmic growth at $37^{\circ}$ transferred to $44^{\circ}$ at zero time and maintained in logarithmic growth by periodic dilution.

\begin{tabular}{|c|c|c|c|c|c|c|}
\hline $\begin{array}{c}\text { Time from } \\
\text { transfer } \\
\text { (min.) } \\
(a)\end{array}$ & $\begin{array}{c}\text { No. of } \\
\text { bacteria } \\
\text { examined } \\
(b)\end{array}$ & $\begin{array}{l}\text { Mean no. of } \\
\text { flagella/ } \\
\text { flagellated } \\
\text { bacterium } \\
\text { (c) }\end{array}$ & $\begin{array}{c}\% \text { bacteria } \\
\text { flagellated } \\
(d)\end{array}$ & $\begin{array}{l}\text { Mean no. of } \\
\text { flagella/ } \\
\text { bacterium } \\
\left(=\frac{c \times d}{100}\right) \\
(e)\end{array}$ & $\begin{array}{c}\text { Turbidity } \dagger \\
(f)\end{array}$ & $\begin{array}{c}\text { Flagellar } \dagger \\
\text { amount } \\
(e \times f) \\
(g)\end{array}$ \\
\hline-15 & 50 & $8 \cdot 4$ & 98 & 8.2 & $\mathbf{0 . 2 5}$ & $2 \cdot 05$ \\
\hline 0 & - & - & - & $9 \cdot 0 \ddagger$ & 0.36 & $3 \cdot 24$ \\
\hline 30 & 50 & $8 \cdot 0$ & 100 & 8.0 & $0 \cdot 65$ & $5 \cdot 20$ \\
\hline 60 & 70 & 4.9 & 97 & $4 \cdot 8$ & $1 \cdot 18$ & $5 \cdot 66$ \\
\hline 120 & 100 & $2 \cdot 7$ & 82 & $2 \cdot 2$ & $3 \cdot 6$ & $7 \cdot 92$ \\
\hline 180 & 100 & $2 \cdot 1$ & 58 & $1 \cdot 2$ & $11 \cdot 1$ & $13 \cdot 3$ \\
\hline 240 & 200 & $1 \cdot 6$ & 30 & 0.48 & $37 \ddagger$ & $18 \cdot 0$ \\
\hline
\end{tabular}

* Expt. 2, Table 1.

$\dagger$ Entries in columns $(f)$ and $(g)$ are expressed as per ml. of culture at -15 min., to allow for subsequent dilution.

\$ Interpolated or extrapolated.

Table 5. Decrease in absolute numbers of bacteria with higher numbers of flagella during growth of Salmonella typhimurium strain LT2 at 44. ${ }^{\circ}$

\begin{tabular}{|c|c|c|c|c|c|c|}
\hline \multirow{2}{*}{$\begin{array}{l}\text { Time after } \\
\text { transfer to } \\
44^{\circ} \text { (min.) }\end{array}$} & \multirow{2}{*}{$\begin{array}{c}\text { Factor of } \\
\text { increase } \\
\text { in viable } \\
\text { count }\end{array}$} & \multicolumn{2}{|c|}{$\begin{array}{l}\text { No. of organisms } \\
\text { in sample with } 5 \\
\text { or more flagella }\end{array}$} & \multicolumn{2}{|c|}{$\begin{array}{l}\text { No. of organisms } \\
\text { in sample with } 8 \\
\text { or more flagella }\end{array}$} & \multirow{2}{*}{$\begin{array}{c}\text { Sample } \\
\text { size } \\
\text { (no. of } \\
\text { bacteria) }\end{array}$} \\
\hline & & Presient & Expected $\dagger$ & Present & Expected $\dagger$ & \\
\hline+45 & 1 & 41 & 一 & 34 & 一 & 48 \\
\hline+75 & 1.57 & 29 & 26 & 5 & 23 & 49 \\
\hline+105 & 2.32 & 19 & 35 & 3 & 30 & 100 \\
\hline+135 & $3 \cdot 85$ & 2 & 21 & 0 & 18 & 100 \\
\hline
\end{tabular}

* Data of Expt. 1, Tables 2 and 3.

$\dagger$ Entries are numbers expected on the assumptions that 'all or none' partition of parental flagella occurred at cell division, synthesis of new flagella had ceased, and that parental flagella were not shed during the period of the experiment.

tion at $44^{\circ}$, with some slight increase later. Presumably this decrease was attributable to some shedding of flagella or possibly to lysis of part of the population. It seems that the completeness of the hoped-for cessation of flagella synthesis varied from experiment to experiment. However, in an experiment in which measurable residual synthesis occurred and in experiments in which it did not occur, the mean number flagella/flagellated bacterium decreased steadily, as called for by the 'sharing' hypothesis. 


\section{DISCUSSION}

It should be noted that the simple hypothesis of 'all or none' partition of parental flagella requires modification if it is to be applied to our material. Bisset (1951) envisaged a situation in which a peritrichously flagellated organism of Salmonella typhi reproduced by 'budding'; the parent bacterium retained all the old flagella and the daughter 'bud' grew new flagella. To cover the common case in which nearly $100 \%$ of bacteria are motile (as in strain LT2) one must assume that the new flagella on the daughter are sufficiently long, at the moment of fission, to confer motility and also to be stained and counted. In a culture which is in a steady state with respect to average number flagella/bacterium, the observed mean number flagella/bacterium would result from an averaging of those on bacteria which have just completed fission, of those on bacteria which are just about to divide (and have about twice as many flagella) and of all intermediate classes. On the assumptions that the 'all or none' hypothesis is correct and that synthesis of new flagella ceases abruptly after one mean generation time at $44^{\circ}$, one would expect the mean number flagella/bacterium to decrease to a value between 1 and 0.5 of the original steady-state mean. This decrease would occur as a consequence of divisions initiated before suppression of flagellar synthesis. If a residual synthesis of flagella were to occur in such a system, on the basis of our observations (Table 3) one would expect it to take the form of synthesis of one or a small number of flagella by a minority of the population. Thus the modified 'all or none' hypothesis predicts that at two or three generations after transfer to $44^{\circ}$ a bimodal distribution of number flagella/ flagellated organism will occur with one mode between 0.5 and 1.0 of the original mean, and on the other, due to residual synthesis, at about unity. No such bimodal distribution was found at appropriate times (i.e. Table 2, Exp. 1, 75 and $135 \mathrm{~min}$.; Exp. 2, 60 and $120 \mathrm{~min}$.).

The conclusion that parental flagella are shared between the daughters is well supported by our quantitative evidence. We have shown that parental flagella are not rapidly shed under the physical conditions of our experiments. We have also shown that during growth at $44^{\circ}$ the synthesis of new flagella is curtailed, the mean number flagella/flagellated bacterium decreases steadily towards unity and the absolute numbers of bacteria with higher numbers of flagella decrease. Bisset and co-workers $(1951,1957,1960)$ examined rod-shaped and coccoid organisms and concluded that flagella are retained upon 'mother cells' and that 'daughter cells' or 'buds' are devoid of flagella or have them in an early stage of development. This conflict of views remains unresolved; further work may show that either or both view points are oversimplified. Our conclusion is to some extent an oversimplification; clearly one would not expect two flagella inserted close together near one pole of a cell to become separated to different daughters at the succeeding division. We do, however, suggest that flagella located near opposite poles would pass to different daughters and that the greater the proximity of those flagella to opposite poles the greater the probability that they will pass to different daughters at the next division.

Our results could be accounted for under the 'all or none' hypothesis by assuming that the decrease in mean number of flagella/flagellated bacterium is due to a shedding of flagella which occurs during growth but not under other conditions. 
Although this possibility cannot be eliminated there is no evidence in its favour. Indeed the stability of the unilinear transmission of motility (Stocker, 1956 $a, b$; Quadling \& Stocker, 1957) provides strong evidence that such shedding is infrequent. It is also conceivable that incubation at $44^{\circ}$ may introduce aberrant modes of division. However, studies or the growth of cultures by plate counts, turbidity measurements and by microscop c examination, revealed no abnormality. Our conclusion that flagella are shared out is also supported by indirect evidence obtained during micromanipulation studies on the unilinear transmission of motility from parent to progeny (Stocker, 195i) $a, b$; Quadling \& Stocker, 1957; Quadling, 1958). It was found that in certain situations motile salmonellas transmitted motility to only one or a few descendant bacteria. Evidence was obtained (Quadling, 1958) that such motile descendant bacteria had only one or a small number of flagella each; it was inferred that these llagella were distributed to the daughters at fission until these daughters received one or no flagella each.

Duguid \& Wilkinson (1961) examined, by electron microscopy, the distribution of fimbriae amongst dividing enterobacteria growing under cultural conditions in which fimbriation was diminishing. Most dividing organisms were equally fimbriated at each end, were scantly fimbria at each end, or were completely non-fimbriated. Bacteria which were fimbriated at one end but not at the other were very rare (less than $1 \%$ ). Duguid's observations are therefore concordant with our results. Results similar to ours were obtained with salmonellas by Kerridge $(1960,1961)$ in experiments in which he increased the incubation temperature from $37^{\circ}$ to $44^{\circ}$. His work provides evidence for the reproducibility of our results.

Evidence for the sharing of parental cytoplasmic materials between daughters has been obtained by a number of workers. Benzer (1953) showed that the adaptive $\beta$-galactosidase of Escherichia $c$ si was uniformly distributed, in the absence of inducer, amongst progeny of inluced bacteria. Novick \& Weiner (1957) working with the same system obtained results which could be interpreted by assuming that permease enzyme molecules were randomly distributed to daughter bacteria. Van Tubergen (1959) and Van Jubergen \& Setlow (1961) investigated the distribution of various parental components amongst the progeny during exponential growth of $\boldsymbol{E}$. coli. Specific cell components were labelled by uptake of appropriate tritium-containing nutrient, and the distribution of the labelled parental material amongst the progeny bacteria was determined by microradioautography at intervals after transfer of the bacteria to unlabelled medium. Parental protein (labelled with ${ }^{3} \mathrm{H}$-proline), ribonucleic acid (labelled with ${ }^{3} \mathrm{H}$-uridine) and cell-wall material (labelled with ${ }^{3} \mathrm{H}$-diaminopimelic acid) were distributed randomly amongst the progeny bacteria, whereas parental (leoxyribonucleic acid (labelled with ${ }^{3} \mathbf{H}$-thymidine) was distributed non-randomly ir large structures, stable for at least 5 generations. Cell-wall synthesis appeared to take place along the whole length of the cell wall.

The observations of Bergerser (1953) on Escherichia coli grown in the presence of chloramphenicol suggest that the mature cell wall is not necessarily a 'dead' structure; he showed that under these conditions additional 'growing points' appeared at the sides of some bacteria. Our observations on the behaviour of Salmonella at the conclusion of the logarithmic phase of growth also bear on this point. The mean size of the organ ism was observed under the microscope to decrease to about one quarter that of logarithmic-phase bacteria by direct division of the 
pre-existing soma. Such observations implied that the walls of the bacterial cells were capable of morphological adjustment and were not 'dead' in the sense of being permanently differentiated.

The relevance of our findings on the fate of parental flagella at cell division to the mode of growth of the cell wall of rod-shaped bacteria is not clear. Assuming that bacterial flagella or their hypothetical basal granules are not able to move independently of the cell wall, our results provide evidence for the eventual dispersion of parental cell walls into discrete fragments, at least as many in number as the mean number of flagella per cell when fully flagellated. Van Tubergen (1959) and Van Tubergen \& Setlow (1961) inferred from observations on the distribution amongst the progeny of parental cell-wall material that in Escherichia coli the number of 'intact structures' comprising the cell wall of one bacterium was at least 200 . There is evidence that some areas of the bacterial cell wall (the sites of future cell division) are more active in synthesis than others (Lederberg, 1957; Mitchell \& Moyle, 1957; Murray, Francombe \& Mayall, 1959). Our results do not necessarily conflict with such a concept.

We thank Dr J. P. Duguid for helpful discussion and for reading the manuscript. The technical assistance of Mr H. A. Milne is gratefully acknowledged. This paper is based on part of a Ph.D. thesis submitted by one of us (C.Q.) to the University of London, 1956.

\section{REFERENCES}

Asheshov, I. N. (1941). Papain digest media and standardisation of media in general. Canad. J. publ. Hlth, 32, 468 .

Benzer, S. (1953). Induced synthesis of enzymes in bacteria analysed at the cellular level. Biochem. biophys. Acta, 11, 383.

Bergersen, F. J. (1953). Cytological changes induced in Bacterium coli by chloramphenicol. J. gen. Microbiol. 9, 353.

Bisset, K. A. (1951). The development of the surface structures in dividing bacteria. J. gen. Microbiol. 5, 155.

Bisset, K. A. \& Pease, P. (1957). The distribution of flagella in dividing bacteria. J. gen . Microbiol. 16, 382.

Bisset, K. A. \& Hale, C. M. F. (1960). Flagellar pattern and growth of Bacillus spp. J. gen. Microbiol. 22, 536.

Duguid, J. P. \& Wilkinson, J. F. (1961). Environmentally induced changes in bacterial morphology. In Microbial Reaction to Environment. Symp. Soc. gen. Microbiol. 11, 69.

Kerridge, D. (1960). The effects of inhibitors on the formation of flagella by Salmonella typhimurium. J. gen. Microbiol. 23, 519.

KERRIDGE, D. (1961). The effect of environment on the formation of bacterial flagella. In Microbial Reaction to Environment. Symp. Soc. gen. Microbiol. 11, 41.

LEDERBERG, J. (1957). Mechanism of action of penicillin. J. Bact. 73, 144.

Leifson, E. (1951). Staining, shape, and arrangement of bacterial flagella. J. Bact. 62, 377.

Mrres, A. A. \& Mrsra, S. S. (1938). The estimation of the bactericidal power of the blood. J. Hyg., Camb. 38, 732.

Mrtcheld, P. \& MoyLe, J. (1957). Autolytic release and osmotic properties of 'protoplasts' from Staphylococcus aureus. J. gen. Microbiol. 16, 184.

Murray, R. G. E., Francombe, W. H. \& Mayall, B. H. (1959). The effect of penicillin on the structure of staphylococcal cell walls. Canad. J. Microbiol. 5, 641.

Novick, A. \& Weiner, M. (1957). Enzyme induction as an all-or-none phenomenon. Proc. nat. Acad. Sci., Wash. 43, 553. 
QUADLING, C. (1958). The unilineac transmission of motility and its material basis in Salmonella. J. gen. Microbiol. 18, 227.

Quading, C. \& Stocker, B. A. D. (1956). An environmentally induced transition from the flagellated to the non-flagellated state in Salmonella; the fate of parental flagella at cell division. J. gen. Microbiol. 15, i (abstract).

QuAdling, C. \& STOcker, B. A. D. (1957). The occurrence of rare motile bacteria in some non-motile Salmonella strains. J. gen. Microbiol. 17, 424.

Stocker, B. A. D. (1956a). Bacterial flagella; morphology, constitution and inheritance. In Bacterial Anatomy. Symp. Soc gen. Microbiol 6, 19.

STOcker, B. A. D. $(1956 b)$. Abortive transduction of motility in Salmonella; a nonreplicated gene transmitted through many generations to a single descendant. J. gen. Microbiol. 15, 575 .

van Tubergen, R. P. (1959). Radioautographic studies on Escherichia coli. Ph.D. Thesis, Yale.

van Tubergen, R. P. \& Setlow, R. B. (1961). Quantative radioautographic studies on exponentially growing cultures of Escherichia coli. The distribution of parental DNA, RNA, protein and cell wall amon 7 progeny cells. Biophys. J. 1, 589.

Zinder, N. D. \& Lederberg, J. (1952). Genetic exchange in Salmonella. J. Bact. 64, 679 . 